\title{
Flow and composition of lymph from the ovary and uterus of cows during pregnancy*
}

\author{
W. R. Hein*, J. N. Shelton, M. W. Simpson-Morgan, R. F. Seamark $\ddagger$ and \\ B. Morris
}

Department of Immunology, John Curtin School of Medical Research, Australian National University, Canberra, A.C.T. 2601, Australia and $\ddagger$ Department of Obstetrics and Gynaecology, University of Adelaide, The Queen Elizabeth Hospital, Woodville, South Australia 5011, Australia

\begin{abstract}
Summary. Ovarian or uterine lymph was collected continuously for periods of up to 25 days from 16 cows cannulated at stages of pregnancy ranging from 96 to 278 days post coitum. Blood samples were taken acutely from the ovarian and uterine veins during surgery and periodically from the jugular vein during the course of lymph collection. The flow rate and cell content of lymph was measured and blood and lymph plasma samples were analysed for progesterone, pregnenolone, pregnenolone sulphate, androstenedione, testosterone, oestrone, oestrone sulphate, oestradiol-17 $\beta$, prostaglandin (PG) F-2 $\alpha$, total protein and albumin. There was a high flow rate of proteinrich lymph from luteal ovaries with rates up to $101.7 \mathrm{ml} / \mathrm{h}$ occurring in individual lymphatics over short periods. Peripheral ovarian and uterine lymph contained a low concentration of cells (mean $<10^{5}$ cells $/ \mathrm{ml}$ ) comprising about $82-87 \%$ lymphocytes, $11-14 \%$ macrophages and monocytes and 2-4\% other cells. At all stages of pregnancy, the concentration of progestagens and androgens was higher in ovarian lymph than in uterine lymph or blood plasma. The differences were greatest for progesterone and androstenedione which occurred at 200-fold and 60-fold greater concentration respectively in ovarian lymph than in jugular plasma. When serial $10 \mathrm{~min}$ samples were collected over a 12 -h period, the concentration and output of progesterone in ovarian lymph varied in a phasic manner, ranging from 3.5 to $7.6 \mu \mathrm{M}$ and from 31.7 to $293.1 \mathrm{nmol} / \mathrm{h}$ respectively. There was a positive correlation between the output of progesterone in lymph and the progesterone concentration in jugular blood samples taken every $20 \mathrm{~min}$. During most of pregnancy there was little difference between the concentration of oestrogens in ovarian lymph, ovarian venous plasma and jugular plasma but, during the 3-5 days before calving, these hormones occurred at slightly higher concentration in ovarian lymph. Apart from pregnenolone and androstenedione, all steroids occurred at lower concentrations in uterine lymph than in jugular plasma. Shortly before parturition there was an abrupt increase in the concentration of PGF-2 $\alpha$ in uterine lymph. Lymph reflects more accurately the milieu of tissue cells than efferent blood and further analysis of differences in the concentration of substances in lymph relative to the output in the ovarian and uterine arterial and venous blood may lead to the identification of factors important in local regulatory mechanisms in the reproductive tract.
\end{abstract}

Keywords: lymph; ovary; uterus; cows; pregnancy

*Present address and address for reprint requests: Basel Institute for Immunology, Grenzacherstrasse 487, Postfach CH-4005 Basel, Switzerland. 


\section{Introduction}

In the ewe a large increase in flow of lymph from the ovary is associated with the presence of a corpus luteum (Morris \& Sass, 1966). Likewise the flow of uterine lymph increases during pregnancy (Sass, 1964). Lindner et al. (1964) and Staples et al. (1982) reported the concentrations of steroids in luteal ovarian lymph of the ewe. Ovarian lymph contained a mean progesterone concentration (range 1.5$5 \cdot 1 \mu \mathrm{M}$ ) which was up to 1000 -fold higher than that in jugular vein plasma. A high concentration of prostaglandin (PG) F-2 (up to $3.9 \mathrm{ng} / \mathrm{ml}$ ) has been measured in the uterine lymph of ewes (Rahim et al., 1983). Inhibin has been measured in the ovarian lymph of ewes at concentrations up to $180 \mathrm{U} / \mathrm{ml}$ but was undetectable in ovarian or jugular venous plasma (Findlay et al., 1986). These observations are significant because this lymph is an extension of the fluid which constitutes the milieu of the ovarian and uterine tissue. Furthermore, from a functional standpoint, the lymphatics of the reproductive tract offer an alternative conduit by which endocrine products may be transported to the peripheral circulation, and a source from which products may enter the local arterial circulation along concentration gradients between closely apposed vessels. In the cow the endocrine roles of the ovary and uterus have been previously evaluated from the composition of ovarian and uterine arterial and venous plasma without considering the lymph. This paper describes the long-term collection of lymph from the ovarian and uterine lymphatics of pregnant cows, its characteristics and composition and its significance in endocrine transport.

\section{Materials and Methods}

Animals. Multiparous Friesian cows aged 3-6 years and primiparous Friesian, Charolais, Jersey and Guernsey heifers aged 15-20 months and of known date of mating were housed indoors 5-7 days before surgery and were fasted for $24 \mathrm{~h}$ before operation.

Surgical procedures. Anaesthesia was induced by the intravenous injection of thiopentone sodium at a dose rate of $1 \mathrm{~g} / 90 \mathrm{~kg}$ liveweight and maintained with $1-5 \%$ halothane (Fluothane, I.C.I. Australia, Villawood, N.S.W.) in oxygen administered by a closed-circuit anaesthetic machine. The animal was placed in dorsal recumbency and the reproductive tract located through a mid-ventral laparotomy. The ovary bearing the corpus luteum and the ipsilateral uterine horn and utero-ovarian vascular pedicle were mobilized through the incision which was held open by a Devine retractor. On some occasions $5-10 \mathrm{ml}$ blood were then withdrawn into heparinized syringes from both a uterine and an ovarian vein. The lymphatic ducts draining the ovary were identified by injecting $0 \cdot 2-0 \cdot 3 \mathrm{ml}$ of a sterile solution of Evans blue $(1.0 \%$ in normal saline, $9 \mathrm{~g} \mathrm{NaCl} / \mathrm{l})$ into the corpus luteum. An accessible lymphatic vessel of suitable size was ligated $5-10 \mathrm{~cm}$ from the ovary leaving the other lymph vessels undisturbed. The selected vessel was dissected free of the serosa and a fine silk suture was tied loosely around it. The lymphatic was cut and the tapered end of a vinyl cannula inserted and secured to the mesovarium and broad ligament with 2-3 additional sutures. The lymphatics draining the ipsilateral uterine horn were revealed by injecting $0.05 \mathrm{ml}$ of dye beneath the serosa at several positions along the uterine wall. The cannulated ovarian lymphatic, which by this time had cleared of dye, was checked regularly for evidence of any connections with the injected lymphatics draining the uterine horn. If the previously cannulated lymphatic remained free of dye it was considered to contain exclusively lymph of ovarian origin. A uterine lymphatic was then chosen which would allow cannulation at a position at least $6-7 \mathrm{~cm}$ before its junction with other lymphatics in the utero-ovarian vascular pedicle. In some animals during advanced pregnancy, uterine lymphatics which clearly drained the contralateral uterine horn were selected for cannulation. Provided that either of these conditions was satisfied, the lymphatic was considered to contain only uterine lymph. The selected duct was cannulated and the cannula anchored in the manner described previously. The cannulas were then brought out through a stab incision in the para-lumbar fossa and secured to the skin with purse-string sutures. The abdominal incision was closed with silk sutures and the animal placed in a crush and monitored during recovery from the anaesthetic.

Construction of cannulas. The cannulas used (Fig. 1a) were made as described by Simpson-Morgan (1980). These allowed the continuous infusion of anticoagulant to prevent the lymph from clotting. Provision was also made for a range of expected vessel sizes (Simpson-Morgan et al., 1985) and the cannulas were cut at a size appropriate for the vessel to be cannulated.

Long-term collection of lymph. During experiments animals were held in specially constructed crushes and lymph was collected as shown (Fig. lb). Collection flasks were changed at least twice daily and the weight of lymph collected was measured. The amount by which the lymph had been diluted by the infusion was included in the calculation of results of all assays. During lymph collection, heparinized blood samples were withdrawn periodically from the 


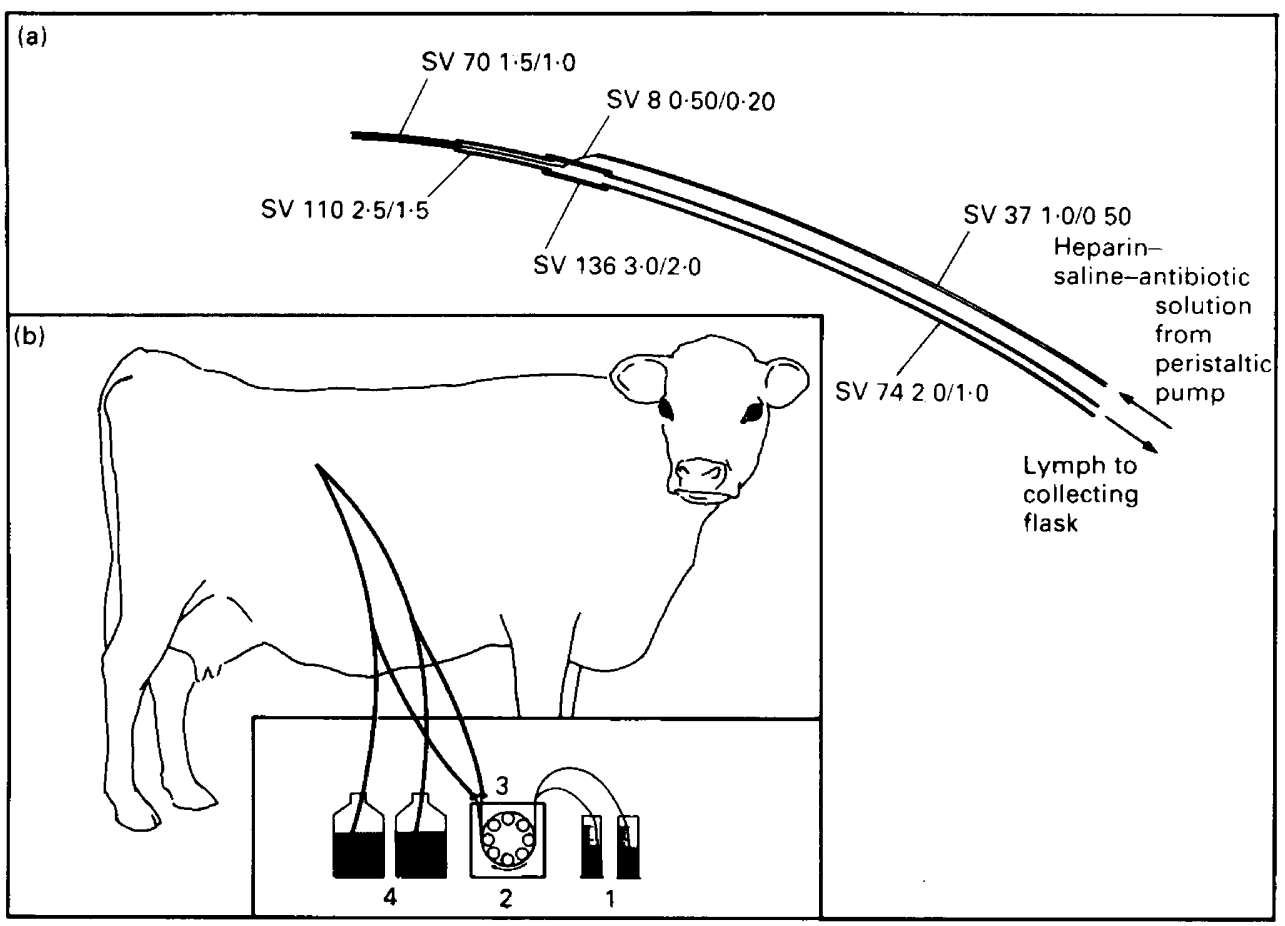

Fig. 1. Schematic diagram showing the methods used to collect lymph from the reproductive tract. (a) Cannulas were made from single lumen vinyl tubing (Dural Plastics and Engineering, Dural, N.S.W., Australia). The manufacturer's catalogue numbers and the tubing sizes used (o.d. $\mathrm{mm} /$ i.d. $\mathrm{mm}$ ) are shown. (b) During collection of lymph, a saline solution containing heparin and antibiotics (see 'Methods') was pumped from graduated cylinders (1) with a peristaltic pump (2). In-line millipore filters (3) $(0.45 \mu \mathrm{m}$, Flow, Meckenheim, West Germany) ensured sterility and prevented blockage of the infusion cannulas. Lymph was collected into plastic flasks (4).

jugular vein. Blood samples and a $5 \mathrm{ml}$ portion of each lot of lymph collected were centrifuged to remove cells and the plasma stored at $-20^{\circ} \mathrm{C}$ for later assay.

An alternative method was also developed to enable lymph to be collected from free-ranging animals by adapting a standard horse rug as shown (Fig. 2). In this way lymph could be collected from cannulas on either side and anticoagulant/antibiotic solution could be pumped continuously to the cannula tip. Animals were able to move about and graze normally wearing the rug and 2 heifers calved normally while wearing it.

Monitoring of lymph flow patterns. In some experiments, a computerized recording apparatus (M. W. SimpsonMorgan, unpublished) was used to record the temporal pattern of lymph flow from a cannulated vessel. The apparatus was controlled by a microcomputer programmed to monitor and record continuously the flow rate of lymph on a minute-by-minute basis (Simpson-Morgan \& Hein, 1985; M. W. Simpson-Morgan, unpublished). The records of lymph flow were stored on microcomputer diskettes. In one experiment ovarian lymph was collected for successive 10-min intervals over a 12-h period (10:00-22:00 h) from a heifer on Day 213 of pregnancy and the volume of lymph collected during each interval was recorded. Peripheral blood samples were taken every 20 min through an indwelling jugular catheter. Cells were promptly removed from lymph and blood by centrifugation and the plasma stored at $-20^{\circ} \mathrm{C}$ for later assay.

Examination of cells in lymph. The total concentration of leucocytes and the proportion of large cells in lymph were determined using an electronic cell counter (Coulter Model FN, Coulter Electronics). Cytology was done on May Grünwald-Giemsa stained 'Cytospin' preparations.

Measurement of protein. The total protein in blood and lymph plasma was measured using the biuret reaction as described by Gornall et al. (1949). Albumin was measured using the bromcresol green reaction as described by Doumas et al. (1971). Protein standards were prepared from bovine serum albumin fraction V (Sigma Chemical Co., St Louis, MO, U.S.A.) over the range $0-100 \mathrm{mg} / \mathrm{ml}$ and included in each assay.

Hormone determination. Concentrations of pregnenolone, pregnenolone sulphate, progesterone, androstenedione, testosterone, oestrone, oestrone sulphate and oestradiol were measured in plasma and lymph samples by validated 


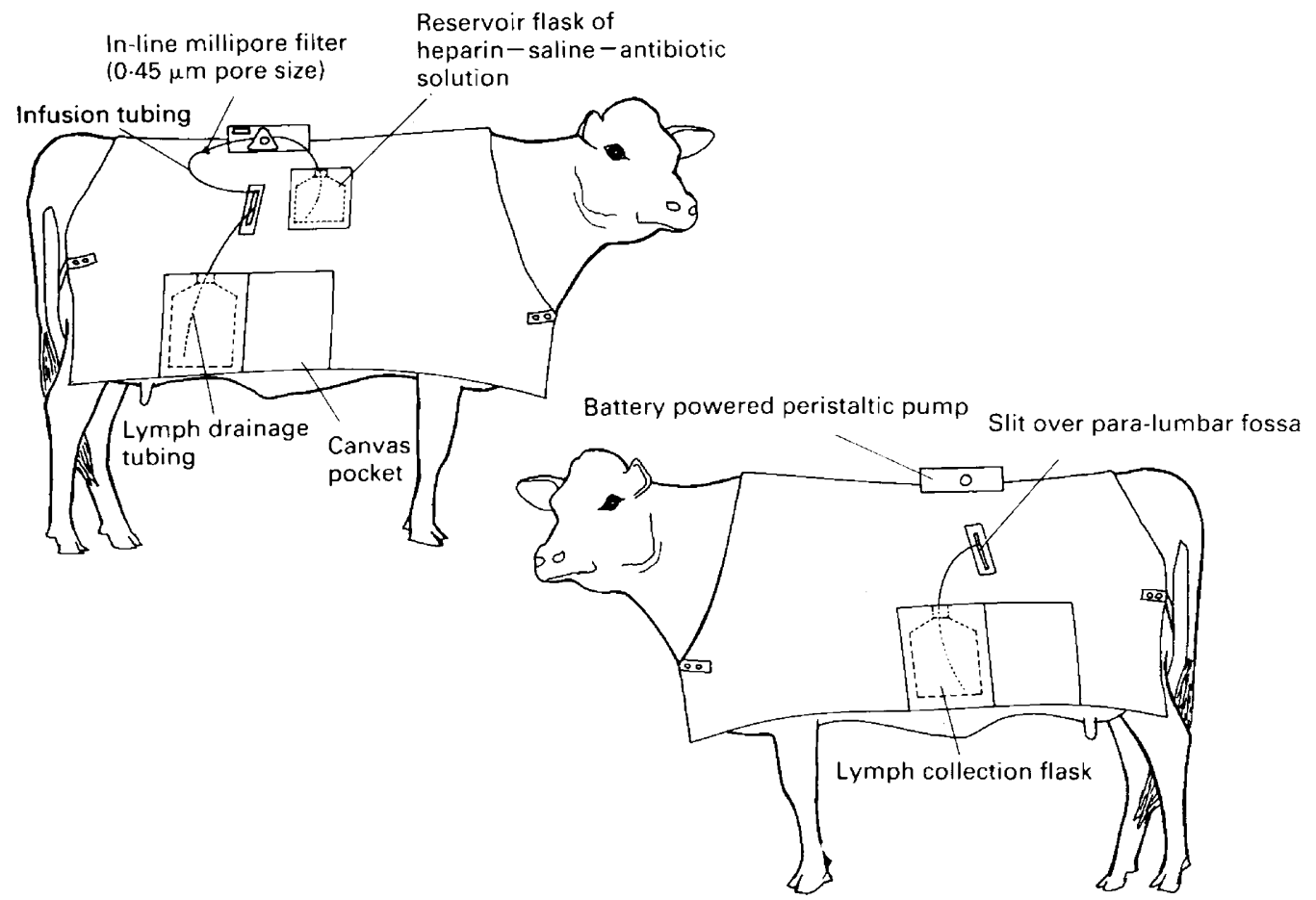

Fig. 2. Diagram illustrating the methods used to collect lymph from free-ranging cows. Lymph was collected into plastic flasks held in canvas pockets from cannulas which emerged through either para-lumbar fossa. A battery-powered peristaltic pump (Everest Electronics, Seaford, S.A., Australia) was attached to the rug over the animal's spine and a saline solution containing heparin and antibiotics was pumped continuously to the tips of the cannulas where it mixed with the lymph to prevent coagulation and bacterial growth in the cannula.

radioimmunoassays. Unconjugated steroid standards were purchased from Steraloids (Wilton, NH, U.S.A.). Pregnenolone-3-sulphate (sodium salt) and oestrone-3-sulphate (potassium salt) were obtained from Sigma Chemical Co. Standard steroids were not recrystallized further.

Solvents for extraction were of analytical reagent grade and were redistilled before use. The solvent:sample ratio (v/v) exceeded 10:1 in all assays. Solvent was evaporated from sample extracts at $37^{\circ} \mathrm{C}$ under air.

To separate unconjugated steroids before radioimmunoassay, solvent extracts of samples were fractionated by column chromatography (hydroxyalkoxypropyl Sephadex; Lipidex, Packard Instrument Company, IL, U.S.A.). Characterization of antisera, and detailed descriptions of the appropriate chromatography and steroid radioimmunoassay methods have been documented (Stone \& Seamark, 1985). All samples were assayed for each steroid component synchronously. PGF-2 $\alpha$ was measured as its methyl oxime as described by Kelly et al. (1986). Intra-assay coefficients of variation were $<10 \%$ in all assays. The limit of sensitivity was $0.4 \mathrm{pmol} / \mathrm{ml}$ for all steroid assays and $0.2 \mathrm{pmol} / \mathrm{ml}$ for the PGF- $2 \alpha$ assay.

Analysis of data. Hormone concentrations in blood plasma and lymph were compared by independent $t$ tests. The records of lymph flow stored on microcomputer diskettes were converted into graphic plots using a dot matrix printer and a plotting program. The plot of lymph flow against time was constructed in the style of a continuous bar graph, in which each vertical line represented the flow of lymph over a 1 -min period.

\section{Results}

\section{Appearance of ovarian and uterine lymphatics}

The utero-ovarian vascular pedicle ipsilateral to the ovary bearing the corpus luteum was always richly supplied with lymphatic vessels apposed closely to the artery and veins. The injection 
of Evans blue into the corpus luteum and the uterine wall clearly demarcated lymphatics draining only the ovary or uterus. The course of ovarian lymphatics was usually confined among the vessels of the vascular pedicle. The uterine lymphatics began as an extensive network of fine subserosal vessels in the uterine wall from which larger collecting ducts emerged and travelled towards the vascular pedicle where they frequently anastomosed with the lymphatics draining the ovary. During the first 3-4 months of pregnancy it was difficult to cannulate lymphatics solely of uterine origin since nearly all accessible large vessels occurred within the ipsilateral vascular pedicle. As pregnancy progressed, larger uterine lymphatics were accessible at locations more remote from the pedicle and, from about 200 days onwards, it was possible to identify lymphatics beneath the ventral serosal surface of the uterus which clearly drained the contralateral horn.

\section{Lymph flow from cannulated lymphatics}

Ovarian or uterine lymphatics were cannulated in 16 cows at stages of pregnancy ranging from 96 to 278 days. One animal was cannulated on two separate occasions. From 17 operations, ovarian lymphatics were cannulated in 13 cows and uterine lymphatics in 12 cows (Table 1). Cannulas remained patent for periods ranging from 2 to 25.5 days and mean collection periods of 9 and 8 days were recorded for ovarian lymph and uterine lymph respectively. In all cows except one, a single vessel only from each organ was cannulated. In Heifer K66, two closely apposed ovarian lymphatics were cannulated separately. The mean of the average flow rate of ovarian lymph in all animals was $22.5 \mathrm{ml} / \mathrm{h}$ (range $1 \cdot 0-70.5 \mathrm{ml} / \mathrm{h}$ ). Within animals, the flow rate varied slightly from one collection period to another and usually peaked $2-4$ days after cannulation. The highest individual flow rate recorded at this time was $101.7 \mathrm{ml} / \mathrm{h}$ over an 8 -h collection period from Cow 67 . The mean flow rate of uterine lymph was $10 \cdot 1 \mathrm{ml} / \mathrm{h}$ (range $1.4-29.8 \mathrm{ml} / \mathrm{h}$ ) (Table 1 ).

Lymph flow was monitored during the preparturient period in Heifers $\mathrm{K} 68$ and $\mathrm{K} 69$, cannulated on Days 275 and 278 of pregnancy respectively. The flow of lymph from an ovarian lymphatic in Heifer $\mathrm{K} 68$ followed the usual pattern and increased in rate over the first 2 days after cannulation. After a period of steady flow at $35-40 \mathrm{ml} / \mathrm{h}$, lymph flow stopped over a 10 -h collection period. The heifer calved $16 \mathrm{~h}$ after the final collection of ovarian lymph. Uterine lymphatics cannulated in Heifers K69 and K68 flowed at slow but regular rates of $1.5 \mathrm{ml} / \mathrm{h}$ and $2.4 \mathrm{ml} / \mathrm{h}$ until $24 \mathrm{~h}$ before and $8 \mathrm{~h}$ after calving respectively.

Pregnancy continued until term in 12 of the 16 animals used in these experiments. Cow 71 aborted twin fetuses at the end of the lymph collection period and Heifer 516 died. Cows 67 and G23 were not seen to abort but returned to oestrus 6-12 weeks after collection finished.

\section{Pattern of lymph flow}

The pattern of lymph flow in an ovarian lymphatic of Heifer K61 was recorded continuously over the period 186-193 days of pregnancy using the computer-linked monitoring apparatus (Fig. 3). Lymph flow followed a rhythmic pattern in that short intervals of much slower flow occurred every 60-90 min. These intervals did not appear to be affected by the posture of the animal. The flow of uterine lymph was different in that it followed a less regular pattern and was more variable in rate (Fig. 4). For example, the average flow rate of uterine lymph recorded over $238 \mathrm{~h}$ from Heifer K66 was $21.0 \mathrm{ml} / \mathrm{h}$. However, when monitored continuously by computer for $72 \mathrm{~h}$, flow rates above $60 \mathrm{ml} / \mathrm{h}$ were recorded for short periods.

\section{Cellular composition of lymph}

The output of total leucocytes and large cells was greatest immediately after surgery and declined over the first 5 days of lymph collection to a plateau level. Although there was some variation between animals, the average total cell concentration in the two types of peripheral lymph 
Table 1. The duration of collection and the average flow rates of ovarian and uterine lymph collected from cows at stages throughout pregnancy

\begin{tabular}{|c|c|c|c|c|c|c|c|}
\hline \multirow{2}{*}{\multicolumn{2}{|c|}{ Cow No. }} & \multirow[b]{2}{*}{ Breed } & \multirow{2}{*}{$\begin{array}{l}\text { Stage of } \\
\text { pregnancy } \\
\text { at } \\
\text { cannulation } \\
\text { (days)* }^{*}\end{array}$} & \multicolumn{2}{|c|}{ Collection period (h) } & \multicolumn{2}{|c|}{ Average flow rate $(\mathrm{ml} / \mathrm{h})$} \\
\hline & & & & $\begin{array}{l}\text { Ovarian } \\
\text { lymph }\end{array}$ & $\begin{array}{l}\text { Uterine } \\
\text { lymph }\end{array}$ & $\begin{array}{l}\text { Ovarian } \\
\text { lymph }\end{array}$ & $\begin{array}{l}\text { Uterine } \\
\text { lymph }\end{array}$ \\
\hline & 71 & Friesian & 96 & 612 & & $19 \cdot 6$ & \\
\hline & 67 & Friesian & 103 & 252 & 288 & $70 \cdot 5$ & $29 \cdot 8$ \\
\hline \multirow{2}{*}{$\mathrm{GC}$} & 9 & Jersey & 109 & 144 & 264 & $15 \cdot 6$ & \\
\hline & 68 & Friesian & 121 & & 432 & & $4 \cdot 3$ \\
\hline GC & 22 & Jersey & 129 & 444 & & 38.8 & \\
\hline \multirow{2}{*}{$\mathrm{K}$} & 61 & Guernsey & 183 & 298 & 48 & $58 \cdot 6$ & 11.9 \\
\hline & 513 & Charolais & 200 & 89 & 257 & 1.0 & $6 \cdot 3$ \\
\hline GC & 9 & Jersey & 202 & & 248 & & 1.7 \\
\hline G & 23 & Friesian & 206 & 288 & & $2 \cdot 8$ & \\
\hline \multirow[t]{2}{*}{ GC } & 20 & Jersey & 207 & 354 & & $22 \cdot 2$ & \\
\hline & 512 & Charolais & 209 & 72 & 72 & $2 \cdot 4$ & $6 \cdot 9$ \\
\hline \multirow[t]{2}{*}{$\mathrm{K}$} & 66 & Guernsey & 209 & $159 / 144 \ddagger$ & 283 & $15 \cdot 9 / 12 \cdot 3$ & $21 \cdot 0$ \\
\hline & 494 & Charolais & 214 & & 160 & & $10 \cdot 1$ \\
\hline \multirow[t]{2}{*}{$\mathbf{K}$} & 67 & Guernsey & 238 & 41 & & $9 \cdot 1$ & \\
\hline & 516 & Charolais & $260 \S$ & 137 & 137 & $16 \cdot 1$ & $23 \cdot 7$ \\
\hline K & 68 & Guernsey & $275^{\circ}$ & 90 & 114 & $30 \cdot 2$ & $2 \cdot 4$ \\
\hline $\mathbf{K}$ & 69 & Guernsey & 278 & & 184 & & $1 \cdot 5$ \\
\hline \multirow{2}{*}{\multicolumn{2}{|c|}{$\begin{array}{l}\text { Mean } \\
\mathrm{n}\end{array}$}} & & & 223 & 207 & $22 \cdot 5$ & $10 \cdot 1$ \\
\hline & & & & 14 & 12 & 14 & 12 \\
\hline
\end{tabular}

${ }^{*}$ Date of mating or insemination $=$ Day 0 of pregnancy.

tLymph flow data collected during the $24 \mathrm{~h}$ immediately after surgery were not considered.

†To ovarian lymphatic vessels were separately cannulated.

$\S$ Stage of pregnancy estimated from uterine and fetal size.

after the first 5 days of collection was always below $2 \times 10^{5} \mathrm{cells} / \mathrm{ml}$ (Table 2). There was no difference between the mean proportion of large cells detected in ovarian or uterine lymph and no obvious relationship between the stage of pregnancy and the total cell or large cell output and concentration in lymph. Granulocytes, chiefly neutrophils, predominated in the first samples collected after cannulation but the proportion of these cells fell quickly over the next 5 days of collection as the proportion of lymphocytes increased. After 5 days there was little change in the relative proportion of each cell type. There was virtually no difference between the cellular composition of ovarian and uterine lymph (Table 2). Most of the other cells present in lymph collected from 5 days on after cannulation were eosinophils.

\section{Protein content of lymph}

The mean concentration of total protein in ovarian lymph and in uterine lymph represented $68.9 \%$ and $44.8 \%$ respectively of the mean total protein concentration measured in peripheral blood plasma (Table 3). The albumin to globulin ratio was highest in uterine lymph (Table 3).

\section{Concentration of hormones in blood and lymph plasma during pregnancy}

Progestagens. Large differences occurred between the concentrations of progestagens measured in samples of blood and lymph plasma collected from cows between Days 136 and 240 of pregnancy (Table 4). The progestagen content of ovarian venous plasma was greater than that in jugular venous or uterine venous plasma (progesterone and pregnenolone sulphate, $P<0.005$; pregnenolone, $P<0.05$ ), but there was no difference between the concentrations of pregnenolone or pregnenolone 

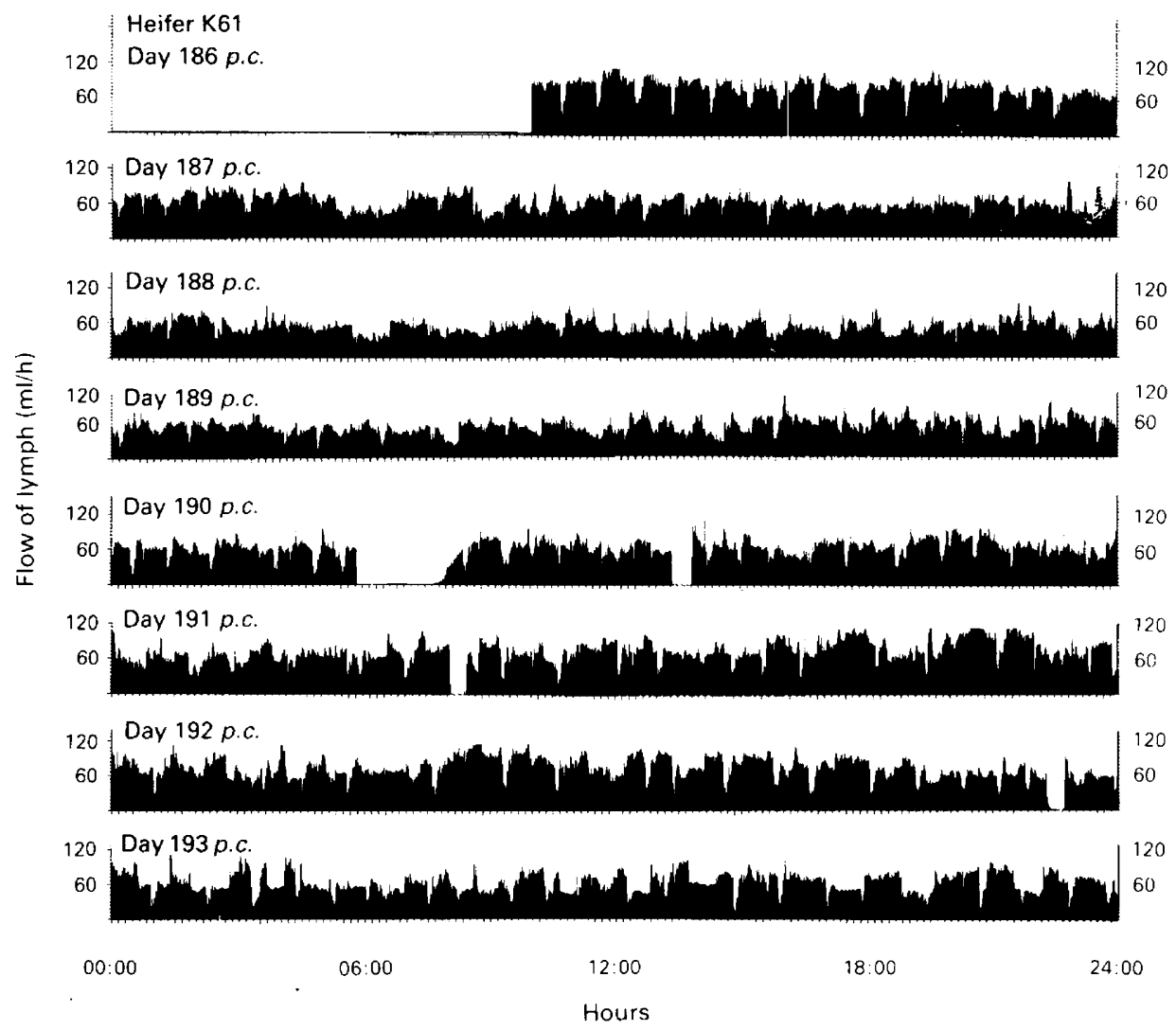

Fig. 3. The pattern of flow of ovarian lymph from Heifer K61. A single lymphatic vessel in the sub-ovarian plexus was cannulated on Day 183 post coitum. Lymph flow continued for 12 days and the pattern recorded by a computerized monitor over the period 186-193 days p.c. is shown. A saline solution containing heparin and antibiotics was not infused into the cannula during collection from this particular animal and the graph shows the actual flow rate of lymph. The 2-h period of zero flow on Day 190 was caused by a temporary blockage of the cannula.

sulphate in jugular venous plasma and uterine venous plasma and the concentration of progesterone was significantly lower in uterine venous plasma $(P<0.05)$. Ovarian lymph contained all progestagens at significantly higher concentrations than in all other samples $(P<0.005)$. The difference was greatest for progesterone, for which the concentration in ovarian lymph was over 200 times greater than in jugular venous plasma and more than 10 times greater than in ovarian venous plasma. There was no difference between the concentration of progesterone in uterine lymph and uterine venous plasma. The concentration of pregnenolone was higher $(P<0.005)$ while the concentration of pregnenolone sulphate was lower $(P<0.005)$ in uterine lymph than in uterine venous plasma.

Androgens. The concentration of androgens (Table 4) in ovarian vein plasma was higher than that in jugular vein or uterine vein plasma (androstenedione, $P<0.025$; testosterone, $P<0.005$ ). There was no difference in the concentration of androstenedione or testosterone between jugular vein and uterine vein plasma. The concentration of androgens in ovarian lymph was higher than in samples from all other sources $(P<0.005)$, with the level of androstenedione in particular being about 60 times higher than in jugular vein plasma and 9 times higher than in ovarian vein plasma. Androstenedione also occurred at higher concentration in uterine lymph than in either jugular vein plasma or uterine vein plasma $(P<0 \cdot 005)$. 


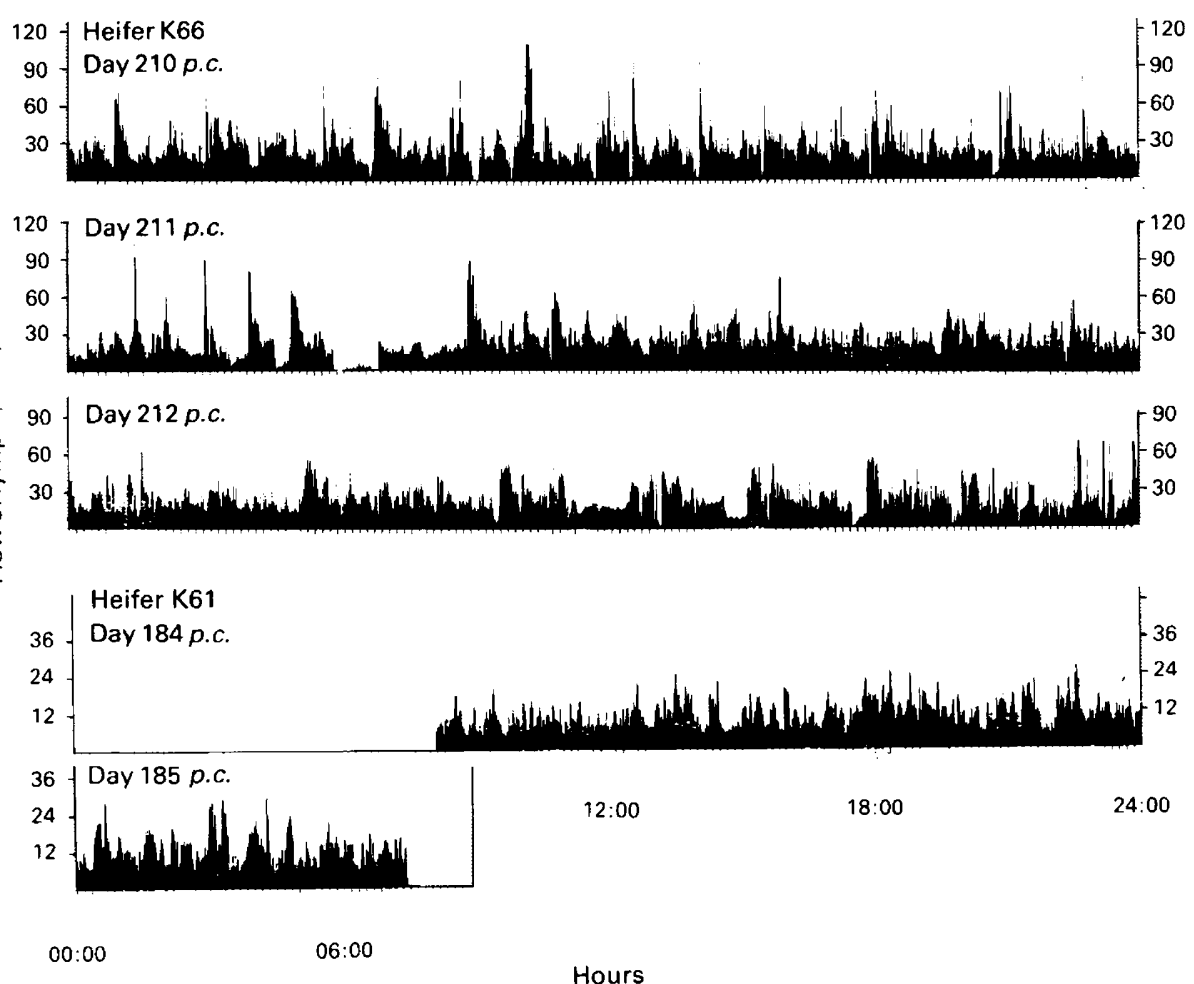

Fig. 4. The pattern of flow of uterine lymph from Heifers K61 and K66. A large lymphatic draining the ipsilateral uterine horn of Heifer K61 was cannulated on Day 183 p.c. and lymph flow was monitored for $24 \mathrm{~h}$ commencing on Day 184 p.c. In Heifer K66, a lymphatic vessel which clearly drained the contralateral uterine horn was cannulated on Day 209. Lymph flow was monitored for $72 \mathrm{~h}$ starting on Day 210 . On both occasions, a saline solution containing heparin and antibiotics was infused at the cannula tip at a constant rate of $1 \mathrm{ml} / \mathrm{h}$ and this component is included in the flow rates as recorded in the graph.

Table 2. The concentration of total and large cells and the differential leucocyte content of ovarian and uterine lymph

\begin{tabular}{|c|c|c|c|c|c|c|c|c|}
\hline \multirow[b]{2}{*}{ Lymph } & \multirow[b]{2}{*}{$\mathrm{N}$} & \multicolumn{2}{|c|}{$\begin{array}{l}\text { Cell concentration } \\
\left(\text { cells } / \mathrm{ml} \times 10^{-3}\right)\end{array}$} & \multirow[b]{2}{*}{$\begin{array}{l}\% \\
\text { large }\end{array}$} & \multirow[b]{2}{*}{$\mathrm{N}$} & \multicolumn{2}{|c|}{ Differential counts $(\%)$} & \multirow[b]{2}{*}{ Other } \\
\hline & & Total & Large & & & Lymphocytes & $\begin{array}{l}\text { Macrophages } \\
\& \text { monocytes }\end{array}$ & \\
\hline Ovarian & 8 & $37 \cdot 4 \pm 9 \cdot 8$ & $8 \cdot 3 \pm 2 \cdot 3$ & $23 \cdot 4 \pm 2 \cdot 0$ & 3 & $84 \cdot 5 \pm 2 \cdot 2$ & $12 \cdot 8 \pm 0 \cdot 6$ & $2 \cdot 7 \pm 1 \cdot 5$ \\
\hline Uterine & 6 & $95 \cdot 5 \pm 15 \cdot 9$ & $23 \cdot 2 \pm 4 \cdot 7$ & $24 \cdot 1 \pm 2 \cdot 3$ & 4 & $85 \cdot 7 \pm 2 \cdot 3$ & $11.8 \pm 0.8$ & $2 \cdot 5 \pm 1 \cdot 7$ \\
\hline
\end{tabular}

Data are expressed as mean \pm s.e. $\mathrm{N}=$ number of animals. The results shown are from observations made from 5 days after cannulation and the number of observations on individual animals ranged from 2 to 40 .

Oestrogens. There were no significant differences $(P>0.05)$ in the concentration of oestrone, oestrone sulphate or oestradiol-17 $\beta$ between blood plasma samples taken from the jugular, ovarian and uterine veins (Table 4). Although oestrogens tended to occur at higher concentration in ovarian 
Table 3. The total protein, albumin and globulin concentration $(\mathrm{g} / 100 \mathrm{ml})$ and albumin/globulin ratio in jugular blood plasma and ovarian and uterine lymph

\begin{tabular}{|c|c|c|c|c|c|}
\hline & $\mathbf{N}$ & $\begin{array}{l}\text { Total } \\
\text { protein }\end{array}$ & Albumin & Globulin & $\begin{array}{l}\text { Albumin/ } \\
\text { globulin }\end{array}$ \\
\hline Jugular plasma & 17 & $7 \cdot 5 \pm 0.17$ & $3.5 \pm 0.08$ & $4 \cdot 0 \pm 0 \cdot 14$ & $0.9 \pm 0.03$ \\
\hline Ovarian lymph & 10 & $5.2 \pm 0.21$ & $2.9 \pm 0.12$ & $2 \cdot 3 \pm 0 \cdot 14$ & $1 \cdot 3 \pm 0.08$ \\
\hline Uterine lymph & 10 & $3 \cdot 4 \pm 0 \cdot 34$ & $1.9 \pm 0.15$ & $1.5 \pm 0.21$ & $1.5 \pm 0.14$ \\
\hline
\end{tabular}

Data are expressed as mean \pm s.e. $\mathrm{N}=$ number of animals. The number of observations on individual animals ranged from 1 to 24 .

lymph than in ovarian vein plasma, the difference was significant only for oestradiol-17 $\beta$ $(P<0.05)$. However, the concentration of all three oestrogens in uterine lymph differed from the concentration in uterine vein plasma. Oestrone $(P<0.025)$ and oestrone sulphate $(P<0.05)$ occurred at lower concentration in uterine lymph than in uterine venous plasma while oestradiol-17 $\beta$ was at a higher concentration in lymph than in plasma $(P<0 \cdot 05)$.

\section{Pattern of progesterone output in ovarian lymph}

The pattern of progesterone transport in a single ovarian lymphatic cannulated in Heifer K66 was monitored over a 12-h period on Day 213 of pregnancy (Fig. 5). The flow rate of ovarian lymph ranged from 7.9 to $45.4 \mathrm{ml} / \mathrm{h}$ and followed a rhythmic pattern especially during the second $6 \mathrm{~h}$ of collection when a number of prominent peaks of flow were evident. The concentration of progesterone in $10 \mathrm{~min}$ fractions of ovarian lymph collected continuously over the $12 \mathrm{~h}$ ranged from $3 \cdot 5$ to $7.6 \mu \mathrm{M}$. There was a significant positive correlation between the rate of lymph flow and the concentration of progesterone in lymph $(r=0.388, P<0.001)$. The progesterone output in ovarian lymph ranged from 31.7 to $293 \cdot 1 \mathrm{nmol} / \mathrm{h}$ and followed closely the pattern of ovarian lymph flow. The peripheral blood concentration of progesterone measured in jugular venous plasma taken every $20 \mathrm{~min}$ over the $12 \mathrm{~h}$ ranged from 14.0 to $30.6 \mathrm{nM}$. There was a significant positive correlation between the output of progesterone in lymph and the concentration of progesterone in jugular venous plasma $(r=0.315, P<0.05)$.

\section{Concentration of hormones in blood and lymph plasma before calving}

Jugular venous plasma and ovarian and uterine lymph were collected from Heifer K68 at intervals over the $100 \mathrm{~h}$ before calving (Fig. 6). The concentration of progesterone and pregnenolone sulphate in jugular venous plasma decreased sharply, starting about 1 day before calving. However, the level of all progestagens in ovarian lymph remained high. The mean concentration of progesterone measured in 8 samples of ovarian lymph collected over the period 100-16 h before calving was $6650 \pm 700 \mathrm{nM}$ and the concentration of pregnenolone in ovarian lymph increased by about 5-fold over the last $10 \mathrm{~h}$ of collection. The concentration of androstenedione and testosterone in jugular plasma and ovarian lymph was within the range detected earlier in pregnancy. The mean concentration of oestrone, oestrone sulphate and oestradiol-17 $\beta$ measured in blood and lymph collected from Heifer K68 was higher than the mean concentration in samples taken from other animals between Days 136 and 240 of pregnancy $(P<0.005)$, although there was a clear trend for the concentration of oestrogens to decline over the $100 \mathrm{~h}$ period before calving (Fig. 6). In contrast to earlier in pregnancy, the concentration of oestrogens was generally higher in ovarian lymph than in jugular plasma. These differences were greatest for oestrone, the mean concentration of which was 22-fold and 8-fold higher respectively in ovarian lymph and jugular plasma during the preparturient period. Apart from pregnenolone and androstenedione, all steroids occurred at lower concentration in uterine lymph than in jugular plasma. The concentration of PGF-2 $\alpha$ in all ovarian lymph samples and in most 
$W . R$. Hein et al.

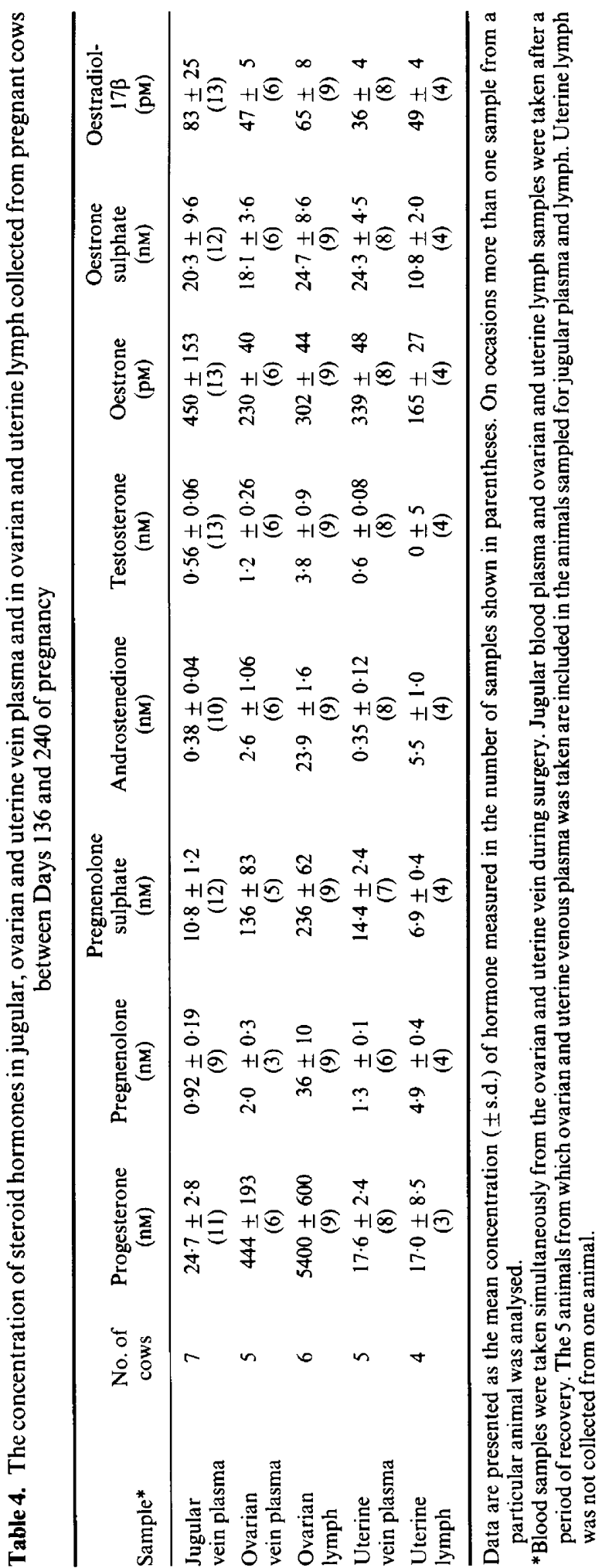




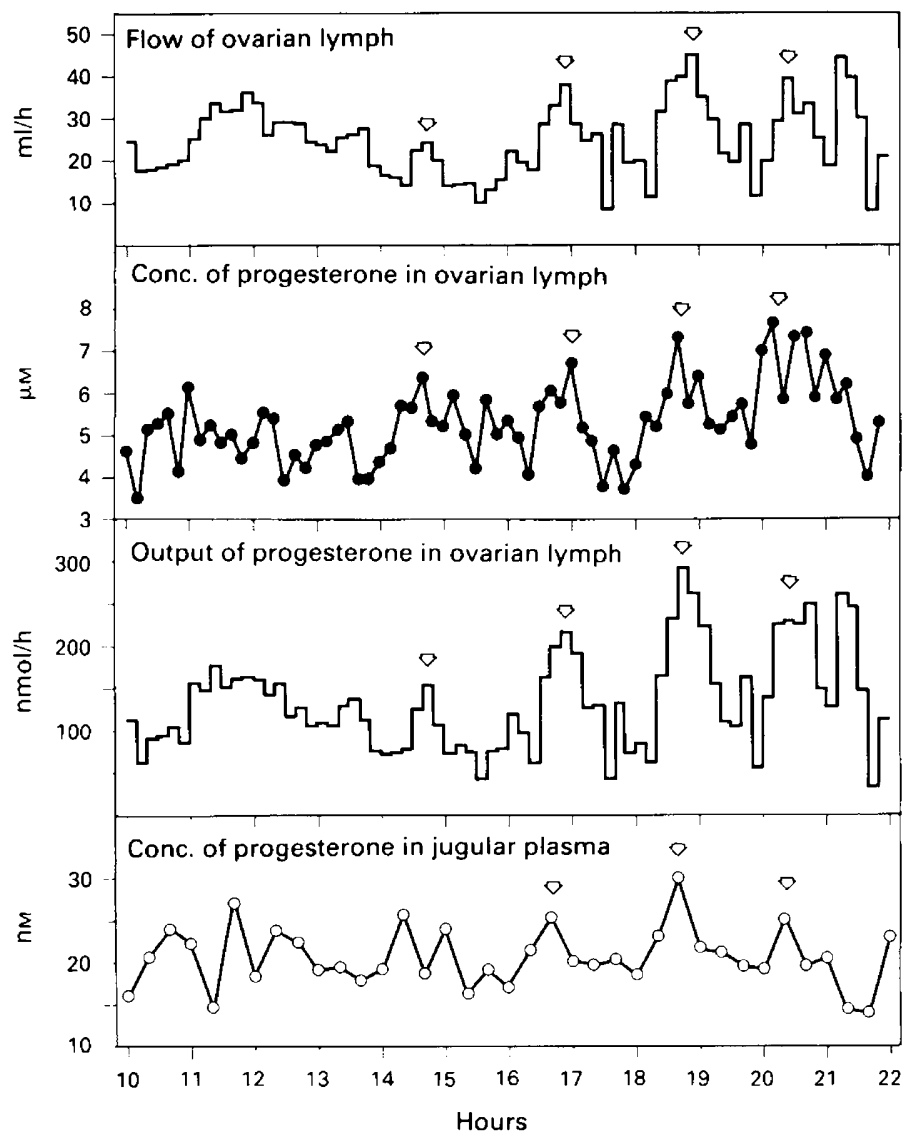

Fig. 5. The flow of ovarian lymph, the concentration and output of progesterone in ovarian lymph and the concentration of progesterone in jugular venous plasma in Heifer K66. Ovarian lymph was collected for successive 10-min intervals over a 12-h period (10:00-22:00 h) on Day 213 of pregnancy and jugular blood samples were taken every $20 \mathrm{~min}$ through an indwelling catheter. On occasions, peaks of lymph flow and progesterone concentration and output in ovarian lymph and progesterone concentration in jugular venous plasma occurred synchronously (arrows).

uterine lymph samples was below the limit of detection of the assay $(50 \mathrm{pg} / \mathrm{ml})$. Uterine lymph collected $4 \mathrm{~h}$ before and at the time of calving contained, respectively, 1.2 and $4.8 \mathrm{ng} \mathrm{PGF}-2 \alpha / \mathrm{ml}$.

Jugular plasma and uterine lymph were also collected from Heifer K69 at intervals from $173 \mathrm{~h}$ until $6 \mathrm{~h}$ before calving. Although the concentration of steroid hormones in samples from this animal differed slightly (data not shown), the overall pattern and relative concentration in lymph and blood plasma were similar to those detected in Heifer K68. The concentration of PGF-2 $\alpha$ in uterine lymph increased from $38 \mathrm{~h}$ before calving, and at $6 \mathrm{~h}$ before calving, when lymph flow ceased, had reached $3.8 \mathrm{ng} / \mathrm{ml}$.

\section{Discussion}

The rates of lymph flow recorded in these experiments do not represent the total flow from the reproductive tract, as only one lymphatic duct was cannulated from the ovary or the uterus. There were usually at least 3-5 ovarian lymphatics present and assuming each carried a similar volume of lymph, the actual production of ovarian lymph may be as much as 3-5 times the volumes recorded. 

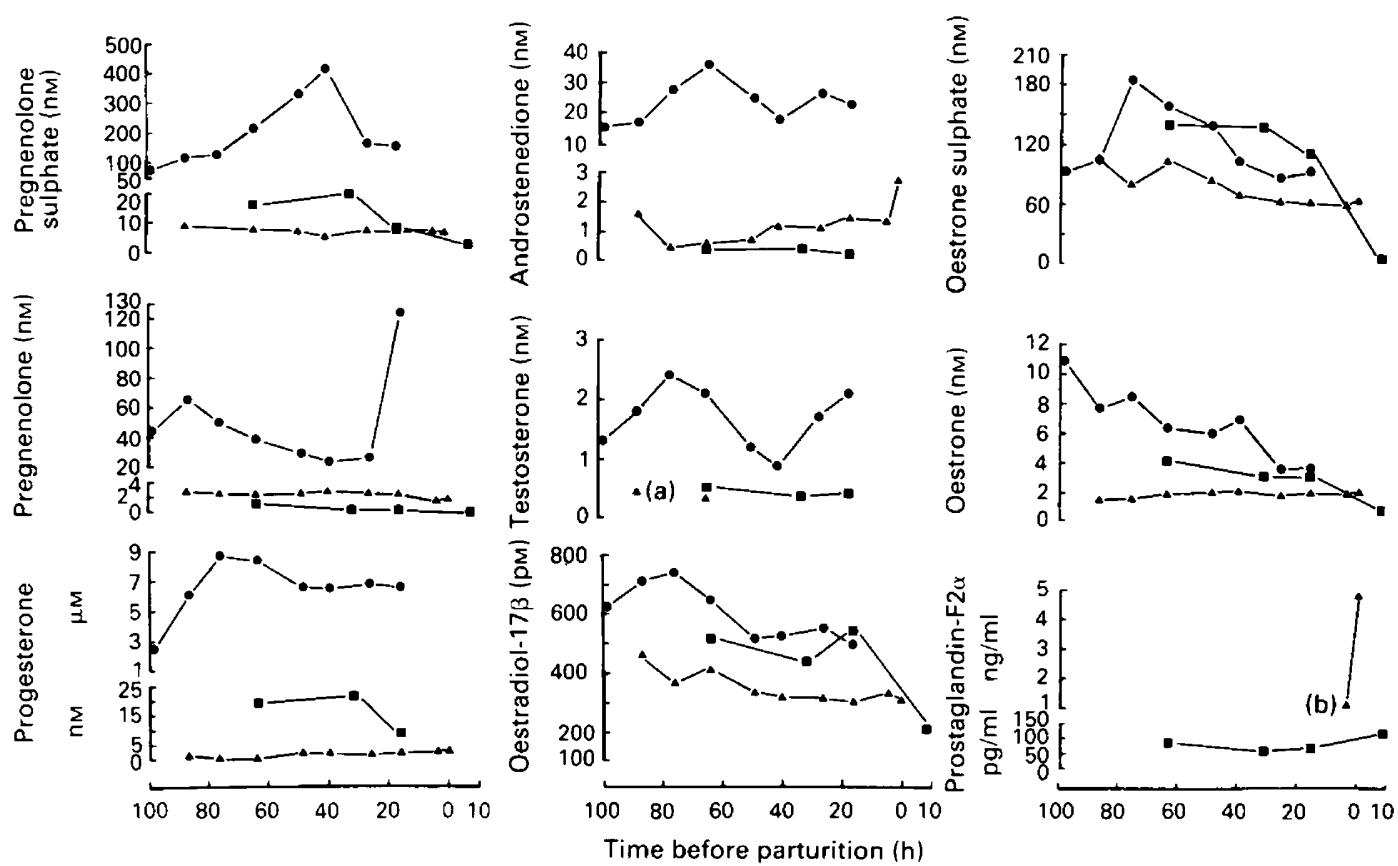

Fig. 6. The concentration of steroid hormones and prostaglandin F-2 $\alpha$ in ovarian and uterine lymph and in jugular plasma collected from Heifer K68 during the preparturient period. (a) Concentrations of testosterone in uterine lymph taken at 76, 49, 40,26, 16 and $4 \mathrm{~h}$ before and at the time of calving were below the assay sensitivity $(0.14 \mathrm{nM})$. (b) Concentrations of prostaglandin F-2 $\alpha$ in uterine lymph samples taken at 87, 76, 64, 49, 40, 26 and $16 \mathrm{~h}$ before calving were below the assay sensitivity $(50 \mathrm{pg} / \mathrm{ml})$. $\bullet$, Ovarian lymph; $\boldsymbol{\Delta}$, uterine lymph; $\mathbf{\square}$, jugular venous plasma.

Estimated lymph flow from luteal ovaries could therefore be of the order of 100-200 ml $/ \mathrm{h}$. Collections of lymph designated as ovarian or uterine were considered authentic in origin and to provide a true reflection of the composition of the interstitial fluid in these organs. All lymph collections were made from ovaries which contained corpora lutea and most of the lymph was considered to be formed within the luteal tissue.

The results demonstrate that large volumes of protein-rich lymph are formed in the ovaries of cows which contain functional corpora lutea. In this respect, lymph formation in bovine ovaries resembles lymph formation in the ovaries of ewes (Lindner et al., 1964; Morris \& Sass, 1966). The total blood flow to the ovary has been shown to increase by up to 3-fold during the luteal phase of the oestrous cycle in cows and to remain high during early pregnancy (Ford \& Chenault, 1981; Wise et al., 1982). Studies in ewes have shown that the blood capillaries of the corpus luteum are especially permeable, particularly during the early stages of its formation and the leakage of protein from the blood to the lymph in the luteal ovary of the ewe per unit weight of tissue is greater than in any other normal organ so far examined (Morris \& Sass, 1966).

The cellular composition of ovarian and uterine lymph of cows was similar to ovarian and uterine lymph of ewes and to peripheral lymph from other tissues (Smith et al., 1970; Staples et al., 1982). The composition of peripheral lymph from different tissues has not been studied as extensively in cattle as in sheep, but the cell content of bovine ovarian and uterine lymph is similar to peripheral lymph from the forelimb (Simpson-Morgan, 1985) and from the tail (B. Morris, unpublished observations).

While a substance present in the lymph in higher concentrations than in the blood is most probably produced locally there are various factors which influence the concentration of materials in lymph 
relative to the blood which must be taken into account. For example, the concentration of substances in the lymph derived from the blood plasma as constituents of the capillary filtrate will be influenced by the effective diffusion diameter of the particular molecule, by the concentration of the substance in the venous plasma, by the availability of molecular transport systems across the capillary membrane, by the presence or absence of binding proteins on either side of the capillary membrane, by the haemodynamics of the blood capillary bed and by whether or not the substance is bound or metabolized by tissue cells. Likewise the metabolic activities of the tissue cells themselves can lead to substantial modifications in the composition of the tissue fluid and lymph due to the secretion of products directly into these fluids (Simpson-Morgan \& Irvine, 1972).

The high concentrations of progesterone, pregnenolone and pregnenolone sulphate in ovarian lymph and in ovarian venous plasma support earlier evidence that the ovary is the main source of progestagens in the cow during pregnancy (Stabenfeldt et al., 1970; Robertson, 1972; Fairclough et al., 1975). The statistically significant correlation between the output of progesterone in ovarian lymph and its concentration in the jugular venous plasma identifies ovarian lymph as an important source of the progesterone in the peripheral plasma. In contrast to a previous study carried out in the ewe on the relative significance of ovarian venous blood and ovarian lymph as a source of progesterone (Lindner et al., 1964), in which it was calculated that the output of progesterone via the ovarian blood was some ten times that which occurred by way of the ovarian lymph, the present results suggest that in the cow progesterone transport by way of the ovarian lymph is quantitatively more important. Assuming an ovarian blood flow of around $25 \mathrm{ml} / \mathrm{min}$ (Wise et al., 1982) and a progesterone concentration in the ovarian venous blood of $\sim 500 \mathrm{nM}$, the output of progesterone via the ovarian blood would be of the order of $750 \mathrm{nmol} / \mathrm{h}$. In contrast, the output of progesterone via the lymph would be of the order of $1100 \mathrm{nmol} / \mathrm{h}$ assuming a lymph flow of around $200 \mathrm{ml} / \mathrm{h}$ and an average concentration of $5500 \mathrm{nM}$.

The phasic changes in the progesterone content of ovarian lymph were similar to those occurring in ovarian venous plasma during the luteal phase of the oestrous cycle and during pregnancy (Walters et al., 1984) and indicate the fluctuations that must be occurring in the steroid content of the ovarian tissues. What these changes mean in physiological terms remains to be determined.

The concentrations of androstenedione and testosterone were higher in ovarian venous plasma than in jugular venous plasma indicating that these androgens are also produced in the ovary. Short (1962) isolated androgens from the ovary of cows but it is still uncertain in which particular tissues these hormones are being produced (Wise et al., 1982). In the data presented here, the much higher levels of androgens in ovarian lymph compared to ovarian venous plasma and the relationship between the rate of lymph flow and the presence or absence of a corpus luteum (Morris \& Sass, 1966) suggest that androgens are produced by luteal tissue during mid- to late gestation in the cow. Shemesh et al. (1975) showed that cells from Day 12 bovine corpora lutea are capable of synthesizing testosterone in vitro. The low levels of oestrogens in ovarian plasma and lymph and in jugular venous plasma are consistent with the results of Savard \& Telegdy (1965) which showed that cells of the bovine corpus luteum lack the enzymes necessary for the conversion of androgens to oestrogens.

As reported by others, the concentration of progesterone in uterine venous plasma was lower than in jugular venous plasma (Comline et al., 1974; Ferrell et al., 1983) and also lower in uterine lymph than in jugular venous plasma. These findings support the view that during mid- to late gestation there is a net uptake of progesterone from the blood by the conceptus and/or the placenta. Although the concentrations of androstenedione in the uterine and jugular venous plasma were not statistically different, the concentration of androstenedione was 15 -fold higher in uterine lymph than in the blood, indicating the high levels of this androgen in uterine tissue fluid. The source of this androstenedione is not certain but it may be a metabolic consequence of the apparent uptake of progesterone by the uterus. The relative concentrations of oestrone and oestradiol-17 $\beta$ in uterine venous plasma and jugular venous plasma gave no direct support to the idea that these oestrogens are synthesized by tissues of the gravid uterus (Hoffman et al., 1976; Ferrell \& Ford, 1980; Ferrell et al., 1983). The concentrations of oestradiol-17 $\beta$ and oestrone sulphate in uterine lymph were also 
similar to those in jugular venous plasma. Oestrone occurred at a lower concentration in lymph than in the venous plasma, indicating that it may be metabolized by uterine tissues. However, if any oestrogens synthesized by the conceptus were conjugated at the site of synthesis (Hoffman et al., 1979) the present results would not accurately reflect the events of oestrogen metabolism in the uterus.

The apparent interrelationship between pregnenolone, pregnenolone sulphate and progesterone synthesis within the ovary warrants further study. The dramatic rise in the pregnenolone content of lymph, at about the time that the levels of progesterone in the peripheral venous plasma began to decline, indicates a possible reduction in the capacity of ovarian tissues to convert pregnenolone to progesterone. The oestrogen content of most samples of ovarian lymph collected during the preparturient period was higher than in the jugular venous plasma whereas earlier in pregnancy the levels were similar in the two fluids. These results indicate that, while the preparturient corpus luteum synthesizes significant amounts of steroids, the relative production of the different steroids and their metabolism varies throughout pregnancy.

In general, uterine lymph collected from preparturient heifers contained lower concentrations of steroids than did jugular venous plasma although two steroids, pregnenolone and androstenedione, were present in slightly higher concentrations in lymph than in plasma. Comline et al. (1974) reported high concentrations of oestrogens in uterine venous plasma of preparturient cows. Placental tissues of cows are known to be able to synthesize oestrogens (Hoffman et al., 1976; Evans \& Wagner, 1981; Larsson et al., 1981) but the low concentrations of oestrogen found in uterine lymph suggested that the uterine tissues were removing oestrogens from the tissue fluid during the last few days of gestation.

The sudden increase in the concentration of PGF-2 $\alpha$ in uterine lymph 1-2 days before calving from $<0 \cdot 1 \mathrm{ng} / \mathrm{ml}$ to peak levels of $3 \cdot 8-4.8 \mathrm{ng} / \mathrm{ml}$ coincides with increases in PGF- $2 \alpha$ concentrations in utero-ovarian venous plasma. PGF- $2 \alpha$ originating from the uterine tissues is considered to play an important role in luteolysis and in the induction of parturition in the cow (Bazer \& First, 1983). It is thought that the transmission of PGF- $2 \alpha$ from the uterus to the ovary occurs primarily by diffusion from the uterine venous plasma to the ovarian arterial plasma across the interstitial fluid and the vascular walls (Wolfenson et al., 1985). The presence of a large PGF-2 $\alpha$ gradient between the uterine lymph and the ovarian arterial plasma offers a more likely pathway for the local transfer of prostaglandin. This has been shown to occur in the ewe (Heap et al., 1985) and to cause premature luteal regression (Whylie et al., 1984; Staples \& Whylie, 1984).

We thank Judy Turner, Sylvia Deam and Fred Amato for expert technical assistance and Gordon Hughes for care of the experimental animals.

\section{References}

Bazer, F.W. \& First, N.L. (1983) Pregnancy and parturition. J. Anim. Sci. 57, Suppl. 2, 425-460.

Comline, R.S., Hall, L.W., Lavelle, R.B., Nathanielsz, P.W. \& Silver, M. (1974) Parturition in the cow: endocrine changes in animals with chronically implanted catheters in the foetal and maternal circulations. $J$. Endocr. 63, 451-472.

Doumas, B.T., Watson, W.A. \& Biggs, H.C. (1971) Albumin standards and the measurement of serum albumin with bromcresol green. Clin. Chim. Acta 31, 87-96.

Evans, G. \& Wagner, W.C. (1981) In vitro oestrogen synthesis by bovine placenta during pregnancy and induced parturition. Acta endocr., Copenh. 98, 119-125.
Fairclough, R.J., Hunter, J.T. \& Welch, R.A.S. (1975) Peripheral plasma progesterone and utero-ovarian prostaglandin $\mathrm{F}$ concentrations in the cow around parturition. Prostaglandins 9, 901-914.

Ferrell, C.L. \& Ford, S.P. (1980) Blood flow, steroid secretion and nutrient uptake of the gravid bovine uterus. J. Anim. Sci. 50, 1113-1121.

Ferrell, C.L. \& Ford, S.P., Prior, R.L. \& Christenson, R.K. (1983) Blood flow, steroid secretion and nutrient uptake of the gravid bovine uterus and fetus. J. Anim. Sci. 56, 656-667.

Findlay, J.K., Tsonis, C.G., Staples, L.D. \& Cahill, R.N.P. (1986) Inhibin secretion by the sheep ovary. $J$. Reprod. Fert. 76, 751-761.

Ford, S.P. \& Chenault, J.R. (1981) Blood flow to the 
corpus luteum-bearing ovary and ipsilateral uterine horn of cows during the oestrous cycle and early pregnancy. J. Reprod. Fert. 62, 555-562.

Gornall, A.G., Bardawill, C.J. \& David, M.M. (1949) Determination of serum proteins by means of the biuret reaction. J. biol. Chem. 177, 751-766.

Heap, R.B., Fleet, I.R. \& Hamon, M. (1985) Prostaglandin F-2a is transferred from the uterus to the ovary in the sheep by lymphatic and blood vascular pathways. J. Reprod. Fert. 74, 645-656.

Hoffman, B., Wagner, W.C. \& Gimenez, T. (1976) Free and conjugated steroids in maternal and fetal plasma in the cow near term. Biol. Reprod. 15, 126-133.

Hoffman, B., Wagner, W.C., Hixon, J.E. \& Bahr, J. (1979) Observations concerning the functional status of the corpus luteum and the placenta around parturition in the cow. Anim. Reprod. Sci. 2, 253-266.

Kelly, R.W., Deam, S., Cameron, M.J. \& Seamark, R.F. (1986) Measurement by radioimmunoassay of prostaglandins as their methyl oximes. Prostaglandins, Leukotrienes \& Medicine 24, 1-14.

Larsson, K., Wagner, W.C. \& Sachs, M. (1981) Oestrogen synthesis by bovine foetal placenta at normal parturition. Acta endocr., Copenh. 98, 112-118.

Lindner, H.R., Sass, M.B. \& Morris, B. (1964) Steroids in the ovarian lymph and blood of conscious ewes. $J$. Endocr. 30, 361-376.

Morris, B. \& Sass, M.B. (1966) The formation of lymph in the ovary. Proc. R. Soc. B 164, 577-591.

Rahim, S.E.A., Bland, K.P. \& Poyser, N.L. (1983) Prostaglandin $F 2-\alpha$ and $\mathrm{PGE}_{2}$ in uterine lymph during the oestrous cycle in sheep. Prostaglandins, Leukotrienes \& Medicine 10, 157-161.

Robertson, H.A. (1972) Sequential changes in plasma progesterone in the cow during the oestrous cycle, pregnancy, at parturition and post-partum. Can. J. Anim. Sci. 52, 45-658.

Sass, C.M.B. (1964) Lymphatic system of the reproductive organs in pregnancy. MSc. thesis, Australian National University, Canberra.

Savard, K. \& Telegdy, G. (1965) Steroid formation in the bovine corpus luteum. Steroids 5, Suppl. 2, 205-210.

Shemesh, M., Hansel, W. \& Concannon, P.W. (1975) Testosterone synthesis in the bovine corpus luteum. Biol. Reprod. 13, 490-493.

Short, R.V. (1962) Steroids present in the follicular fluid of the cow. J. Endocr. 23, 401-411.

Simpson-Morgan, M.W. (1980) Automatic lymph collection. In Festschrift for F. C. Courtice, pp. 195-202. Ed. D. Garlick. University of New South Wales, Sydney.

Simpson-Morgan, M.W. (1985) The effects of lymph node extirpation on lymph flow. In Progress in Lymphology, pp. 53-54. Eds J. R. Casley-Smith \& N. B. Piller. University of Adelaide Press.

Simpson-Morgan, M.W. \& Hein, W.R. (1985) Patterns of lymph flow. In Progress in Lymphology, pp. 53-54.
Eds J. R. Casley-Smith \& N. B. Piller. University of Adelaide Press.

Simpson-Morgan, M.W. \& Irvine, C.H. (1972) Transcapillary exchange of protein-bound hormones from the bloodstream to the tissue fluid. Acta endocr., Copenh., Suppl. 158, 128-141.

Simpson-Morgan, M.W., Travella, W., Hugh, A.R., McClure, S. \& Morris, B. (1985) The long-term collection of lymph from single lymph nodes of foetal lambs in utero. Aust. J. exp. Biol. med. Sci. 63, $397-409$.

Smith, J.B., McIntosh, G.H. \& Morris, B. (1970) The traffic of cells through tissues: a study of peripheral lymph in sheep. $J$. Anat. 107, 87-100.

Stabenfeldt, G.H., Osburn, B.I. \& Ewing, L.L. (1970) Peripheral plasma progesterone levels in the cow during pregnancy and parturition. Am. J. Physiol. 218, 571-575.

Staples, L.D. \& Whylie, P.A. (1984) Contribution of the utero-ovarian lymphatic network to the control of corpus luteum function in the ewe. In Reproduction in Sheep, pp. 122-124. Eds D. R. Lindsay \& D. T. Pearce. Australian Academy of Science, Canberra.

Staples, L.D., Fleet, I.R. \& Heap, R.B. (1982) Anatomy of the utero-ovarian lymphatic network and the composition of afferent lymph in relation to the establishment of pregnancy in the sheep and goat. J. Reprod. Fert. 64, 409-420.

Stone, B.A. \& Seamark, R.F. (1985) Steroid hormones in uterine washings and in plasma of gilts between Days 9 and 15 after oestrus and between Days 9 and 15 after coitus. J. Reprod. Fert. 75, 209-221.

Walters, D.L., Schams, D. \& Schallenberger, E. (1984) Pulsatile secretion of gonadotrophins, ovarian steroids and ovarian oxytocin during the luteal phase of the oestrous cycle in the cow. J. Reprod. Fert. 71, 479-491.

Whylie, P.A., O'Shea, J.D. \& Staples, L.D. (1984) Infusion of PGF-2 $\alpha$ into uterine lymphatic ducts causes luteolysis in the ewe. Proc. Aust. Soc. Reprod. Biol. 16, 4, Abstr.

Wise, T.H., Caton, D., Thatcher, W.W., Rami Lehrer, A. \& Fields, M.J. (1982) Androstenedione, dehydroepiandrosterone and testosterone in ovarian vein plasma and androstenedione in peripheral arterial plasma during the bovine oestrous cycle. J. Reprod. Fert. 66, 513-518.

Wolfenson, D., Thatcher, W.W., Drost, M., Caton, D., Foster, D.B. \& LeBlanc, M.M. (1985) Characteristics of prostaglandin $F$ measurements in the ovarian circulation during the oestrous cycle and early pregnancy in the cow. $J$. Reprod. Fert. 75, 491-499.

Received 14 September 1987 